\title{
Microsomal Triglyceride Transfer Protein Large Subunit
}

National Cancer Institute

\section{Source}

National Cancer Institute. Microsomal Triglyceride Transfer Protein Large Subunit. NCI Thesaurus. Code C116416.

Microsomal triglyceride transfer protein large subunit ( $894 \mathrm{aa}, \sim 99 \mathrm{kDa}$ ) is encoded by the human MTTP gene. This protein plays a role in the targeting of triglycerides, cholesteryl esters, and phospholipids to membranes or vesicles. 